Article

\title{
The Impact of Incumbent Scandals on Senate Elections, 1972-2016
}

\author{
Nicholas Chad Long \\ Department of Political Science, Global Studies, Environmental Science and Policy, School of Behavioral and \\ Social Sciences, St. Edward's University, Austin, TX 78704, USA; chadl@stedwards.edu
}

Received: 22 February 2019; Accepted: 29 March 2019; Published: 5 April 2019

\begin{abstract}
In recent decades, a growing body of literature focused on the effects of scandals on congressional elections. The studies concluded that scandals decrease candidates' vote totals, and that certain types of scandals have a more deleterious effect than others. Virtually all of these studies focus on House elections. The obvious differences between the two chambers calls into question the applicability of these findings for Senate elections. This study examines the impact that incumbent scandals had on senatorial elections from 1972 to 2016. Scandals are categorized based on the nature of the transgression in order to determine if the type of scandal made a difference. The results reveal that senators seeking reelection while confronting a scandal suffered a $4 \%$ decrease in the popular vote. Scandals involving political misdeeds, financial improprieties, and controversial statements hurt incumbents the most. Scandals also attracted challengers who spent more money against the incumbents.
\end{abstract}

Keywords: Congress; campaigns and elections; political candidates; voting behavior; scandals

\section{Introduction}

As evidenced by the 2018 midterm election, scandals still have the power to shape the political environment. Al Franken's (D-MN) alleged behavior toward women prompted increased scrutiny during the \#MeToo movement, causing him to resign instead of running for reelection. The Democratic Party was forced to spend money in the usually dependable state of New Jersey because of the negative coverage surrounding Robert Menendez's (D-NJ) corruption trial. These two senators join a long list of individuals whose careers were impacted by scandals, and the presence of scandals in political life is likely to be with us well into the future. As James Madison observed centuries ago, we are not governed by angels.

While the nature of political scandals can at times be titillating, their effect on our political system calls for sober analysis. As Miller (1999) notes, "government legitimacy is the foundation of every democracy. Concerns about the vitality of democracy arise, therefore, when public trust in political leaders and institutions falls" (721). It should come as no surprise that unethical behavior undermines trust in those manifesting the behavior (Abramowitz 1991; Dancey 2012), but what may not be as obvious are the negative repercussions on essential institutions like political parties (Cobb and Taylor 2014) and Congress (Herrick 2003; Hibbing and Theiss-Morse 1995; Patterson and Caldeira 1990), not to mention the government as a whole (Bowler and Karp 2004; Ornstein 1993).

Though scandals occur frequently in American politics and have a corrosive effect on the system, they were, until fairly recently, largely ignored by scholars. Kebschull (1992) laments that "political scandal and corruption seem to remain distinctly at the fringes of the concerns of political scientists" (706). Similarly, Markovits and Silverstein (1988) describe the research agenda as "barely in its infancy" (1). In the quarter-century since these assessments, several insightful works were published, but there is still much to learn about the various aspects of this phenomenon. 
Most of the recent studies examine the effects of scandals on candidates for the House of Representatives, with scant attention paid to the Senate. The inattention to the Senate is concerning because there are enough differences between the two chambers to make findings from studies of the House potentially inapplicable to the Senate. George Washington's famous metaphor of a saucer cooling a hot cup of tea is evidence that the two chambers were intended to be distinct, and even with all of the changes in our political system over the past two hundred years, they still retain unique characteristics. There are several ways that these differences could affect the dynamics of a scandal.

The most obvious difference is the longer length of term for the Senate. Because senators stand for election every six years, the timing of scandals has more relevance for them. If a scandal occurs early in a senator's term, there is the possibility that he can ameliorate any political wounds before facing voters. On the other hand, a scandal occurring early in a senator's term might give an exceptionally qualified opponent plenty of time to prepare to capitalize on that vulnerability when the campaign begins.

A second difference is the composition of the electorate. Members of the House commonly represent homogenous districts, while the states that senators represent have more diversity. Thus, representatives are likely to face a uniform reaction to a scandal based on the socioeconomic traits of their districts (e.g., a sex scandal in a socially conservative district or a financial scandal in a working-class district). In contrast, senators need to brace for a variety of reactions, especially if they represent large states that encompass discrete communities.

A third difference is the amount of money that senators raise compared to their counterparts in the House. Incumbents from both chambers operate under the same campaign finance regulations, but senators almost always have a more extensive network of contributors and raise larger sums of money from those contributors. The increased number of financial interactions makes senators more susceptible to campaign finance violations (Thompson 1995). Similarly, powerful interest groups and individuals will seek out senators because of the wide range of policy areas in which they are involved. The line between helping supporters navigate the federal bureaucracy and wielding improper influence on behalf of those supporters is a perilous one. Because many senators are prominent figures on the national political stage, such missteps are more likely to be covered by the media than those of House members (Romano 2014).

The purpose of this study is to contribute to the literature on scandals in American politics by providing information about the Senate. I compile a comprehensive list of incumbents involved in scandals over several decades. This list, along with other relevant variables, allows me to determine whether being caught in a scandal impacted decisions to seek reelection and, for those senators that did seek reelection, whether it proved harmful at the polls. I categorize the types of scandals in an effort to determine whether certain scandals inflict more damage than others. I examine the effect of scandals on the quality of candidates challenging incumbent senators and the influence of money in elections. The findings in this study will hopefully be illuminating in their own right, and will mark a path forward for future research on the topic.

\section{Literature Review}

An interesting question is why an active research agenda emerged in recent decades, where none existed before. One explanation is the existence of cases. As Bauer and Hibbing (1989) point out, "in the 1950s and for most of the 1960s, scandalous revelations concerning members of Congress were rare, and it was even more unusual for the objects of these revelations to have the moxie to run for reelection" (267-68). By the 1970s, one did not have to look far to encounter political malfeasance. Garment (1992) observes that in the first 15 years after President Nixon's resignation, "more than 400 relatively senior officials and candidates for federal office ... have been publicly accused in the national press of personal wrong doings" (3). Are the individuals who sought elected office since the 1970s less moral than those from earlier time periods or are other factors responsible for the increase in scandals? The consensus is that the latter is true. 
Part of the explanation centers on the role of the media. Since Watergate, reporters are willing to investigate official corruption more aggressively than in the past (Heywood 1997; Sabato et al. 2000). Moreover, the rise of candidate-centered campaigns around this same time ushered in an era where personal indiscretions are considered newsworthy (Roberds 2003). Regardless of whether the scandal is based on abuse of office or personal failings, the amount of media coverage has an effect on whether members of Congress are able to survive in office (Chang et al. 2010; Herrick 2000).

Part of the explanation centers on systemic factors. For many decades, a divided government was more common than a unified government in the nation's capital. The failure of parties to consolidate power through the ballot box led them to pursue it through other means, including congressional investigations and legal proceedings (Ginsberg and Shefter 1990; Parker and Dull 2009). The larger society within which politics exists also influences the likelihood that certain types of behavior will be exposed. As Rosenson (2014) writes, "so what is considered ethically problematic and worthy of (indeed demanding) formal inquiry will be inextricably tied to the norms - and the rules, laws, and institutions - of society at some particular time. As the social and political landscape changes, engendering shifts in norms, so will the scope of what is deemed unethical" (229). An example of this is the rise in cases related to sexual misconduct that would have been tolerated in the not too distant past.

Thus, the frequency and variety of scandals in recent years provided scholars with the opportunity to examine them in more depth. Several took this opportunity and approached the subject from multiple angles. One group of articles sought to determine the electoral impact that scandals have on candidates running for office. They consistently found that scandals decrease the percentage of the vote for incumbents, and that the type of scandal matters, although they differ on which types are more damaging (Abramowitz 1988; Basinger 2013; Brown 2006; Peters and Welch 1980; Welch and Hibbing 1997).

Another group of articles examined how voters perceive scandals. They revealed that perceptions will differ based on whether the misdeed relates to an official's formal job function or is more personal in nature, with voters judging the former more harshly. Voters also make distinctions between how they evaluate an official as a person and how they evaluate the job an official is doing (Doherty et al. 2011). Likewise, if people view an official as competent, then this will temper their reaction to any scandals, as was the case with President Clinton (Funk 1996). Voter characteristics like partisan identification, ideology, policy preferences, and regionalism are important factors in how they ultimately judge scandalous behavior among politicians (Brown 2007; Dimock and Jacobson 1995; Miller 1999; Min 2013; Rundquist et al. 1977).

The research agenda on scandals in American politics is no longer in its infancy, but there are noticeable gaps in the literature. As mentioned earlier, the most glaring is the lack of attention paid to the United States Senate. Of the numerous works written over the past quarter-century, almost all focused on the lower legislative chamber. There are only two articles that provide a detailed examination of the upper chamber, and, while both provide useful information, they do have limitations.

Abramowitz's (1988) influential article on Senate elections does not focus exclusively on the impact of scandals, but includes them as one variable among many that can affect election outcomes. For this reason, he does not spend the requisite amount of time on the subject to fully flesh it out. While he provides an estimate of the damage done to candidates in terms of their vote percentages in general elections, he ignores the impact of scandals on retirement decisions and primary losses. He measures challenger quality in Senate elections, but does not examine the interplay between incumbent scandals and the quality of the opposition that incumbents encounter. Perhaps the thing that is most lacking is the kind of nuanced definition of scandal that exists in studies of House incumbents. He utilizes a binary operationalization (i.e., scandal or controversy) based on the presence of a formal investigation into illegal activity. This does not allow one to determine if certain types of scandals have a greater impact at the polls than others. 
Roberds (2003) provided a succinct history of the evolution of ethics investigations, including the creation of the Select Committee on Ethics. An understanding of this committee-especially what it is mandated to do and whether it fulfills that mandate-is important. ${ }^{1}$ By combing through various sources, he created a comprehensive list of Senate ethics cases, dividing them into three periods for evaluation. Although he did highlight some specific cases, there was not a systematic compendium of the types of cases that warranted investigation through the years. Even with a detailed typology of cases, limiting himself to formal institutional inquiries ignores the numerous scandals that did not trigger action by the Ethics Committee. His quantitative analysis was also very basic, relying on percentages of incumbents who won reelection, were defeated, or chose not to seek reelection. This neglects other factors that could be at play in these outcomes, and does not allow one to determine the repercussions of formal investigations on vote totals.

A review of the literature on the electoral effects of scandals makes clear that they have an effect on a member's decision to seek reelection, on the likelihood that the member will face competition in the primary, and on the margin of victory in the general election. A handful of articles looked at the House Bank scandal of the early 1990s and found that the effect of writing bad checks was most evident in the period prior to the general election, with the worst offenders being more likely to retire or suffer defeat in the primary compared to those members who had not written any bad checks (Alford et al. 1994; Banducci and Karp 1994; Jacobson and Dimock 1994). Questions could be raised about the applicability of findings related to this one scandal, but research that encompassed a broader array of incidents reached similar conclusions about the effect on incumbents prior to the general election (Boatright 2013; Brown 2006). ${ }^{2}$

Those members with the fortitude or hubris to seek reelection, and who secure their party's nomination, encounter campaign conditions made more inhospitable by the presence of a scandal. Peters and Welch (1980) found that incumbents who managed to win reelection did so with vote percentages less than what would be expected under normal circumstances. Curiously, Democrats suffered more (11\% drop) than Republicans (6\% drop). Years later, Welch and Hibbing (1997) followed up on that research by investigating whether similar effects were observable during elections in the 1980s as had been found in the 1970s. They discovered that incumbent vote percentages dropped by an average of $9 \%$, with those facing morals charges still suffering the worst blow at the ballot box. Unlike in the previous study, Republicans were more affected (13\%) than Democrats (6\%).

A more recent study by Basinger (2013) that covered the years since Watergate detected a 5\% reduction in an incumbent's vote total. When broken down by category, sex scandals and those involving corruption took the greatest toll. ${ }^{3}$ Abramowitz's (1991) examination of the House estimated a $12 \%$ reduction, although he only analyzed two election cycles; thus, the number of cases was small. For the Senate, the damage was equal to a $7 \%$ drop at the polls (Abramowitz 1988). Such consistent results across numerous studies provide conclusive evidence that scandalous behavior has a negative impact on incumbents in the place that probably matters most: the ballot box. This takes on added significance when one considers that "Congress typically leaves it to the electorate to oust a tarnished incumbent, unless the sullied member exits voluntarily. This implies that the electorate's response to scandal is the primary determinant of representatives' incentives to act ethically and /or morally" (Basinger 2013, p. 386).

1 Another excellent resource on the history of this committee is the Congressional Research Service report titled Senate Select Committee on Ethics: A Brief History of Its Evolution and Jurisdiction by Jacob R. Straus. Also of interest is the same organization's reports titled Enforcement of Congressional Rules of Conduct: An Historical Overview by Jacob R. Straus and Expulsion and Censure Actions Taken by the Full Senate Against Members by Jack Maskell.

2 Conversely, Welch and Hibbing (1997) found that "a corruption charge only marginally increases the odds a member will depart voluntarily" and that "primary defeats are even rarer than voluntary departures" (232-33).

3 Not all research found that immoral and sexual scandals have a greater effect than other types. Carlson et al.'s (2000) experimental analysis revealed that financial scandals harm candidates' character ratings more than sexual scandals. Interestingly, female candidates suffer less from scandals than men. 
There are incumbents who manage to survive reelection. The incumbency advantage enjoyed by members of Congress translates into large margins of victory, thus providing them with a buffer at the polls (Erikson 1971; Gelman and King 1990; Jacobson 2009; Mayhew 1974). This allows some tainted incumbents to withstand a loss of support at the polls and still retain their seats. In some instances, the initial wave of disapproval by a candidate's supporters dissipates by the time they cast their ballots, such that the electoral effect is dampened (Vonnahme 2014).

However, surviving one election cycle does not mean that the member is off the hook. Praino et al. (2013) found that "incumbents recover much of their lost margins in their first post-scandal election, but it is not until four to six years after the scandal that their predicted vote share approaches the level one would expect had they never been involved in a scandal in the first place" (1046). Scandals can also be detrimental to those with progressive ambition, in that it precludes them from seeking higher office (Kiewiet and Zeng 1993). Additionally, it makes sense that a member's standing on Capitol Hill would be diminished by inappropriate conduct, making it harder for that member to achieve legislative victories and accrue the benefits that come with tenure.

\section{Materials and Methods}

The most critical aspect of any study concerned with the impact of political scandals on electoral outcomes is how to define a scandal. Previous research revealed a plethora of approaches to this task. Some scholars confined themselves to cases where there was a formal investigation by the House or Senate Ethics Committees (Praino et al. 2013; Roberds 2003; Rosenson 2014). Others included cases involving investigations by law enforcement agencies, including criminal indictments and convictions (Abramowitz 1991; Herrick 2000; Puglisi and Snyder 2011). These approaches had the advantage of relying on objective criteria. Documentation will exist for any committee investigations or actions within the criminal justice system. A researcher does not have to make a judgment call about whether behavior falling outside the scope of these criteria rises to the level of a scandal.

A weakness of these approaches is that they excluded objectionable behavior that negatively impacted the member of Congress. For example, Roger Jepsen (R-IA) applied for membership in a "health spa" that was later closed for prostitution, and George Allen (R-VA) used a racial epithet when addressing a young man working on his opponent's campaign. Neither of these episodes resulted in investigations by the Ethics Committee or law enforcement agencies, but they were primarily responsible for the senators losing their seats. In order to account for such incidents, some scholars included cases reported by the press that raised questions about an incumbent's honesty, judgment, and competence (Abramowitz 1988; Basinger 2013; Brown 2007; Peters and Welch 1980; Romano 2014; Welch and Hibbing 1997).

My approach mirrors that of the latter group of scholars. Any incident resulting in an inquiry by the Senate Select Committee on Ethics; in an investigation, arrest, indictment, or conviction within the criminal justice system; and in coverage by reputable news organizations was coded as a scandal. To ensure as comprehensive a list as possible, I used a wide variety of sources. ${ }^{4}$

There are four works that focused on congressional ethics (Baker 1985; Butler and Wolff 1995; Congressional Quarterly 1992; Thompson 1995). Several publications compiled lists of wrongdoing by public officials, including members of the Senate (Grossman 2008; Long 2007; Roberts 2001). There are other books written for a general audience that covered the topic of congressional scandals (Kessler 1997; Marion 2010; Tolchin and Tolchin 2001). Abramowitz and Segal's (1992) book on Senate elections highlighted numerous episodes of misbehavior by members. The Almanac of American Politics continues to be an invaluable resource for scholars. I also combed through back issues of the

4 In addition to the sources mentioned in the text, Stephen Roberds was kind enough to share the list he compiled for his research on the history of ethics investigations in the Senate. 
Congressional Quarterly (CQ), specifically the special issues published in October of each election year. ${ }^{5}$ As noted by Welch and Hibbing (1997), "since CQ's data come from its survey of local media and its local contacts, if reports of charges appear in the $C Q$, they have been circulated widely enough to appear in local media coverage of the race" (229). In 2005, Citizens for Responsibility and Ethics in Washington (CREW) began releasing an annual report of the most corrupt members of Congress. Finally, the chairperson and ranking member of the Ethics Committee put out occasional press releases with information about investigations that the committee is undertaking.

Once a list of scandals is compiled, then one must decide how to categorize them. The aforementioned studies served as a guide for how to approach this task. One thing that I considered important was to distinguish between transgressions that violate the law, as opposed to those that violate institutional rules or societal norms. Behavior that results in criminal investigations places incumbents in greater jeopardy because they not only have to deal with the prospect of electoral defeat, but possibly prison time for serious charges. It is not always the case that the public will view an incident that is under criminal investigation as more troubling than one that is not (e.g., a violation of campaign finance law compared with a lurid sex scandal); however, in general, behavior that garners the attention of law enforcement agencies is more serious than other types of scandals. For this reason, I created a dummy variable that indicated scandals of a criminal nature. Similarly, I created a dummy variable to show which scandals led to inquiries by the Ethics Committee. There was also a dummy variable denoting those cases where both law enforcement and the committee investigated a scandal.

Previous studies usually tried to make distinctions between scandals of a personal nature versus those that in some way involved the office. Anyone can fall prey to temptations of the flesh, but not just anyone can ask for money in exchange for inserting favorable language into a bill. Anyone can lie on a tax return, but not just anyone can accept an illegal campaign contribution from a foreign entity. To gain a fuller understanding of the nature of political scandals, these distinctions are important.

Scholars were in agreement on the broad categories that need to be included, although each took a slightly different approach. I adopted the classification scheme used by Basinger (2013), but with one important modification. I included a category highlighting verbal gaffes that created problems for incumbents. None of the previous studies explicitly measured the effect of controversial statements on vote totals, either ignoring them or placing them in a catch-all "other" category. The number of such instances and the clear impact that many had on campaigns suggested it warranted a separate category. That addition resulted in six categories of scandal.

Corruption included bribery, conspiracy, obstruction of justice, and influence peddling. Financial Scandals included inadequate financial disclosures, tax evasion or fraud, illegitimate outside income, conflict of interest, illegal gratuities and gifts, improper employment practices, and converting campaign funds for personal use. Political Scandals included election fraud, campaign finance violations, and abuse of official perquisites. Sex Scandals included extramarital affairs, solicitation of a prostitute, sodomy, sexual assault, sexual harassment, and retaining an employee on the payroll for immoral purposes. Controversial Statements included the use of offensive language (e.g., racial epithets and sexist remarks), utterances of an incendiary nature, and assertions that made a senator appear especially ignorant or incompetent. The final category was a potpourri that covered all of the Other problematic behaviors that incumbents display.

Senators serve longer terms than members of the House, which means that the opportunity for several missteps exists. It stands to reason that one mistake in the first year of a term is surmountable because five years are left to make amends with constituents. However, a string of mistakes over the course of several years may be a bridge too far. Even if the scandals are not deemed that serious, the accumulation of them can cause voters to call into question the temperament of the incumbent.

5 Beginning with the 2006 midterm election, comprehensive coverage of each Senate race can be found on the CQ Politics website (now Roll Call Politics). 
For this reason, I took note of the number of separate scandalous incidents that occurred within a single election cycle.

I coded the partisan affiliation of incumbents, as well as their length of tenure in the Senate. ${ }^{6}$ While I had no reason to think that officeholders of one party are more prone to exhibit objectionable behavior than those from the other, it was nonetheless worth exploring. I did have reason to think that fewer scandals would be attached to those with more seniority. The longer public officials are in office, the more political wisdom they acquire, making it is easier to avoid the pitfalls that more inexperienced politicians fall prey to. Moreover, if that wisdom, on occasion, is not enough to prevent foolish behavior, then familiarity with the system enables more experienced senators to deflect unwanted attention. To put it more cynically, they are better at hiding unethical behavior.

There were 608 instances of an incumbent seeking reelection in the general election during this time period. Of these, $48(8 \%)$ involved an incumbent touched by scandal. There were an additional 21 instances of incumbents involved in a scandal either leaving office or losing in the primary. Other professionals are not scrutinized to the extent of politicians; thus, it is impossible to say whether this is in line with the level of unethical behavior in other fields. For those that think it is higher than expected, I reiterate that the definition of scandal used for this project covers a wide range of behavior. It is not as if one in ten senators were accepting bribes. For example, Thomas Eagleton (D-MO) being dropped from the presidential ticket because of a history of mental illness called his competence into question, but hardly made him an unethical person.

Table 1 presents basic characteristics of the scandals. The leading categories were corruption and financial scandals. Corruption included blatant acts of bribery (e.g., the Abscam sting operation led to Harrison Williams Jr.'s (D-NJ) imprisonment), but most cases in this category involved senators using their influence on behalf of friends and contributors in inappropriate ways (e.g., the Keating Five). More than one-third of financial improprieties involved officeholders accepting illegal gifts (e.g., the defense contractors' hospitality scandal), with a few instances of senators appearing to enrich themselves (e.g., Bill Frist (R-TN) was investigated for insider trading).

Table 1. Characteristics of incumbent scandals, 1972-2016. D-Democrat; R-Republican.

\begin{tabular}{cccc}
\hline Type of Scandal & & & \\
\hline Corruption & 22 & $12(\mathrm{D})$ & $10(\mathrm{R})$ \\
\hline Financial & 21 & $8(\mathrm{D})$ & $13(\mathrm{R})$ \\
\hline Political & 11 & $4(\mathrm{D})$ & $7(\mathrm{R})$ \\
\hline Sex & 9 & $2(\mathrm{D})$ & $7(\mathrm{R})$ \\
\hline Statement & 12 & $2(\mathrm{D})$ & $10(\mathrm{R})$ \\
\hline Other & 13 & $7(\mathrm{D})$ & $6(\mathrm{R})$ \\
\hline Type of Investigation & & & \\
\hline Ethics Committee & & 15 \\
\hline Law Enforcement & & 17 \\
\hline Both & & 15 \\
\hline None & & 41 \\
\hline
\end{tabular}

6 Incumbents who ran as Independents are coded as belonging to the party that they caucused with in the Senate (e.g., Bernie Sanders is coded as a Democrat). 
Table 1. Cont.

\begin{tabular}{|c|c|}
\hline Decade & \\
\hline 1970s & $17(14)$ \\
\hline $1980 \mathrm{~s}$ & $23(18)$ \\
\hline 1990s & $22(18)$ \\
\hline $2000 s$ & $20(15)$ \\
\hline $2010 s$ & $6(4)$ \\
\hline \multicolumn{2}{|l|}{ Region } \\
\hline Northeast & $9(9)$ \\
\hline Midwest & $22(15)$ \\
\hline South & $24(20)$ \\
\hline West & $33(25)$ \\
\hline \multicolumn{2}{|l|}{ Terms in Office } \\
\hline Less than One & 4 \\
\hline One & 28 \\
\hline Two & 12 \\
\hline Three & 15 \\
\hline Four & 5 \\
\hline Five & 2 \\
\hline Six & 3 \\
\hline \multicolumn{2}{|c|}{ Number of Scandals per Case } \\
\hline One & 56 \\
\hline Two & 8 \\
\hline Three & 4 \\
\hline Four & 1 \\
\hline \multicolumn{2}{|l|}{ Party } \\
\hline Democrat & 28 \\
\hline Republican & 41 \\
\hline
\end{tabular}

There were 64 individual senators involved in scandals, but four of them (D'Amato, Durenberger, Cannon, and Hatfield) had scandals in multiple election cycles, resulting in 69 cases for this study. Several senators had more than one scandal in an election cycle, resulting in 88 discrete incidents that were coded as scandals, as reflected in the categories for types of scandal and types of investigation.

Half of the cases coded as a political scandal centered on the acceptance of illegal campaign contributions. Incumbents have practical reasons for opposing public financing of campaigns due to their vast fundraising advantage, but it would probably spare them headaches to not have to worry with raising such large sums of money. Most of the sexual scandals involved relationships between consenting adults, but a couple were of a more disturbing nature, such as the sexual harassment allegations against Robert Packwood (R-OR) and sexual assault allegations against Brock Adams (D-WA). Several senators said things that stirred up controversy. These ranged from politically unwise (e.g., Conrad Burns (R-MT) berating firefighters for their poor effort at battling wildfires) to just plain strange (Mark Dayton's (D-MN) announcement that he was closing his offices because of a security threat that did not exist).

There are two things of note when looking at scandals through a partisan lens. Republicans were three times more likely to be involved in a sex scandal and five times more likely to say something controversial. The former is interesting when one considers that social conservatives react to infidelity 
more harshly than other voters (Doherty et al. 2011). In terms of geography, two-thirds of the senators involved in scandals represented southern and western states, while the fewest hailed from the northeast.

Another interesting pattern emerges regarding tenure. Nearly half of all cases involved senators with one term or less of experience. The more terms senators served, the fewer scandals they encountered. This could mean that seniority breeds wisdom, and wisdom enables one to avoid compromising positions. On the other hand, perhaps senior senators are just as prone to sketchy behavior as anyone else, but have the experience to know how to cover their tracks. Yet another possibility is that those who accrue seniority do so because they are good-natured and upstanding individuals. Whatever the reason, it is clear that the initial six years in office can be treacherous.

Senators with one term or less who were ensnared in a scandal were more likely to be defeated than their colleagues with unblemished records. The former senators were defeated $42 \%$ of the time, compared with $15 \%$ for the latter. ${ }^{7}$ These percentages show that senators benefit fairly quickly from the advantages of incumbency and are highly likely to remain in office, unless they suffer ethical lapses that undercut those advantages to the point that challengers are more likely to win the election.

\section{Results}

\subsection{The Effect of Scandals on Incumbents}

Table 2 delineates the electoral fate of those incumbents facing scandals. It is clear that scandals do not automatically cause senators to voluntarily step aside. Only five of the $69(7 \%)$ left office in the middle of their term, with four of these resignations being prompted by very serious allegations. Edward Gurney (R-FL) and Harrison Williams Jr. (D-NJ) stood trial on bribery charges, with the latter being convicted; Robert Packwood (R-OR) and John Ensign (R-NV) were accused of obstructing justice to cover up sexual improprieties; and, although Tom Coburn (R-OK) was caught up in the Ensign scandal, his resignation had more to do with health problems than fallout from his admonishment by the Ethics Committee. Another 14 members (20\%) retired at the conclusion of their term. The events that preceded these retirements were varied and did not necessarily involve criminal behavior.

This is disappointing news for those upwardly mobile congressmen and state officials secretly hoping for a spate of scandals to clear the field of incumbents. Incumbents are not so easily dissuaded from seeking reelection. The power and prestige that accompanies a seat in the United States Senate clearly makes one loath to give it up. This willingness to stand and fight, even in a weakened state, is a trait that helped them to get elected in the first place.

If voluntary removal is uncommon, then removal by a fellow partisan is for all intents and purposes non-existent. An incumbent facing a scandal was defeated in a primary only twice in the $40+$ years covered by this study. ${ }^{8}$ Both candidates-Donald Stewart (D-AL) and Richard Stone (D-FL) - were southern Democrats hurt by press accounts of federal investigations into possible violations of the law. Even though both men were cleared of any wrongdoing, the damage was done.

It is possible to survive a primary only to succumb to defeat in the general election. The fact that incumbents have to deplete valuable resources fending off a strong primary challenge, not to mention the prolonged exposure to negative attacks, creates a steeper path to victory in November. This path is made more treacherous by the presence of a scandal. Senators who encountered opposition in the primary, but were free of scandal, lost in November 15\% of the time. Senators who encountered opposition in the primary, and were burdened by scandal, lost in November $43 \%$ of the time. ${ }^{9}$

7 There were 24 senators serving one term or less that sought reelection while dealing with a scandal; 10 of them were defeated. There were 256 senators serving one term or less that sought reelection without the albatross of scandal; 39 of them were defeated.

8 Incidentally, both primary losses occurred in 1980.

9 A total of 23 incumbents involved in a scandal faced opposition in a primary, with 10 of them losing the general election. A total of 257 incumbents not involved in a scandal faced opposition in a primary, with 39 of them losing the general election. 
Table 2. Electoral outcomes of incumbents involved in a scandal, 1972-2016.

\begin{tabular}{lcccccc}
\hline & 1970s & 1980s & 1990s & 2000s & 2010s & Total \\
\hline Resigned & 1 & 1 & 1 & 1 & 1 & 5 \\
\hline Retired & 1 & 0 & 6 & 5 & 2 & 14 \\
\hline Defeated in Primary & 0 & 2 & 0 & 0 & 0 & 2 \\
\hline Defeated in General Election & 5 & 8 & 1 & 5 & 0 & 19 \\
\hline Won Reelection & 7 & 7 & 10 & 4 & 1 & 29 \\
\hline Total Incumbents in a Scandal & 14 & 18 & 18 & 15 & 4 & 69 \\
\hline$\%$ Running in General Election Who Won & 58 & 47 & 91 & 44 & 100 & 60 \\
\hline$\%$ Returning to Office & 50 & 39 & 56 & 27 & 25 & 42 \\
\hline
\end{tabular}

For incumbents unfortunate enough to be involved in a scandal, the true test of survival is returning to Capitol Hill for another six years. They will deploy a full arsenal of political weaponry in an effort to make that possible, but the countervailing forces of negative media attention, attacks from the opposition, and doubts within the minds of voters can transform that difficult trek into an impossible journey. With this in mind, perhaps the most important question to be answered is whether a scandal makes it more likely that an incumbent will fail to achieve reelection.

During this time period, the reelection rate for senators not involved in a scandal was $87 \%$. In comparison, senators burdened by scandal were victorious only $60 \%$ of the time. ${ }^{10}$ The fact that more than half of the senators tainted by scandal were reelected speaks volumes about the power of incumbency, and the willingness of voters to consider a range of factors when casting their ballots. Nevertheless, no senator wants to head into campaign season with such diminished odds of securing a victory.

The picture was even bleaker with the inclusion of senators who resigned, retired, or were defeated in a primary, as this brought the overall percentage of incumbents returning to office down to a dismal $42 \%$. This clearly demonstrates that incumbents did face negative repercussions for inappropriate behavior. For all of the electoral advantages that accrue to incumbents, encountering a serious scandal is a powerful countervailing force that will, more often than not, end their senatorial careers.

In an era of increased polarization among political elites, partisan control of Congress is of utmost importance. Thus, another question that needs to be addressed is the partisan impact of scandals. It is bad enough for scandals to damage the political prospects of individual office holders, but there are broader implications if scandals reverberate beyond senators to their respective parties. I examined all of the elections in this time frame, including open seat, to determine whether the incumbent's party was able to maintain control of the seat. In the absence of scandal, the incumbent party maintained control of a seat $82 \%$ of the time. With a scandal present, the incumbent party maintained control of a seat $59 \%$ of the time. ${ }^{11}$

These negative electoral effects can be ameliorated for the parties if they can divorce themselves from the offending politicians. In looking at the narrower set of open-seat elections, the incumbent party maintained control of a seat $61 \%$ of the time when no scandal was present, compared to $57 \%$ when the incumbent party's senator was embroiled in a scandal. This means that if incumbent senators involved in a scandal decide not to seek reelection or do not survive their primaries, then their parties

10 For the subset of elections not involving scandal, there were 72 losses out of 560 cases. For the subset of elections involving scandal, there were 19 losses out of 48 cases.

11 There were 608 elections involving an incumbent and 174 open seat elections, for a total of 782 . Of these, 713 did not have a scandal, with the incumbent party maintaining control of the seat $582(82 \%)$ times and losing control 131 (18\%) times. The remaining 69 elections did have a scandal, with the incumbent party maintaining control 41 (59\%) times and losing control $28(41 \%)$ times. 
have basically the same chance of maintaining control of their seats as they would have if the senators were devoid of scandal. In these instances, the incumbent's desire to weather the storm may be at odds with the party's desire to secure the seat, and party loyalists will breathe a sigh of relief should the incumbent exit the scene.

\subsection{The Effect of Scandals on Challenger Quality and Campaign Spending}

Whether an incumbent can survive a scandal has a lot to do with who is on the other side of the net. High-quality challengers have the experience and resources to pose a credible threat under normal circumstances, but that threat is amplified when incumbents are vulnerable. For this reason, one would expect that highly qualified challengers would leap at the opportunity to take on incumbents weakened by scandal. Other than an open-seat race, this scenario presents ambitious politicians with their best chance to climb the political ladder (Brace 1984; Rohde 1979). This exacerbates the dire circumstances of the incumbents, because not only must they deal with the actual scandal, but also with an opponent who has the skills to capitalize on it. With this in mind, it is important to determine whether scandals do in fact attract higher-quality challengers than would normally be the case.

I utilized Lublin's (1994) measure of challenger political quality. ${ }^{12}$ He estimated the impact of challenger experience in various elected offices on the vote for Senate incumbents. Controlling for other factors, he found that members of the House gained a higher proportion of the vote than other elected officials. In other words, members of the House are the highest quality challengers for members of the Senate. His calculations allowed him to estimate the electoral value of other offices as well. The following is his ranking of offices: United States (US) Representative, statewide officials and former senators, local officials, and state legislators. Individuals with no experience in elected office are considered the lowest-quality challengers. I assigned US Representatives a value of four and challengers with no experience in elected office a value of zero, with the other offices in between.

As shown in Table 3, the average score for all challengers was 1.45, meaning that the overall quality of challengers was fairly low during this period. Only $17 \%$ of incumbents faced a member of the House, while $42 \%$ faced an opponent with no previous experience. In keeping with Lublin's findings, this did make a difference. Those senators running against a colleague from the House-regardless of whether the senator was facing a scandal or not-lost $32 \%$ of the time, but only lost $8 \%$ of the time to inexperienced challengers.

When comparing the average score of challengers based on the presence of a scandal, I found that challengers facing scandal-free incumbents had a score of 1.43 , compared to a score of 1.77 for those facing incumbents embroiled in scandals. Thus, incumbents involved in a scandal did face challengers of a slightly higher quality. However, an independent-sample $t$-test revealed that this difference was not statistically significant; therefore, I cannot confirm that scandals have a direct effect on challenger political quality. This surprising result calls for further research.

A pivotal component of elections is campaign spending. Expenditures by both incumbents and challengers rose steadily over the decades, with incumbents spending an average of \$10.15 million and challengers $\$ 5.76$ million in the 2016 election. ${ }^{13}$ Incumbents almost always have more financial resources, but numerous studies revealed that challengers in congressional elections derive greater or equal benefits from their expenditures (Abramowitz 1991; Ansolabehere and Gerber 1994; Jacobson 1978; Kenny and McBurnett 1994). A challenger who can stay within the vicinity of an incumbent in terms of spending can mount a competitive contest.

12 I also used a measure developed by Krasno and Green (1988). I reached the same conclusion with both measures; thus, for the sake of brevity, I only included the Lublin measure in this article. It should be noted that Gary Jacobson (2009) used a dichotomous variable to measure challenger quality, based on whether the challenger ever held elective office. Because the vast majority of Senate challengers do have previous experience in office, I think that a more nuanced measure that takes into account the various types of office is more appropriate for this study.

13 These spending data come from Tables 3-5 on the website of The Campaign Finance Institute. 
High-quality challengers with plenty of money at their disposal pose the most daunting challenge to incumbents; however, as we learned above, high-quality challengers do not automatically appear just because incumbents are dealing with scandals. Because money serves as a force multiplier in elections, even average challengers can appear formidable when standing astride overflowing war chests. Among the factors that determine the amount of money flowing into a challenger's coffer is the perceived vulnerability of the incumbent. If an incumbent enters the campaign in a weakened state, then there should be a greater likelihood of facing a well-financed challenger. Even if a scandal emerges later in the election cycle, online fundraising and the ability to transfer money electronically means that an immediate response will probably come from donors of the incumbent's opponent. Therefore, incumbents involved in a scandal should encounter larger challenger expenditures.

Table 3. Challenger political quality (CPQ). US-United States.

\begin{tabular}{lccc}
\hline CPQ Rating & No Scandal & Scandal & Total \\
\hline 0 & 235 & 17 & 252 \\
\hline No Experience & & & 109 \\
\hline 1 & 100 & 9 & 51 \\
\hline State Legislators & & 2 & \\
\hline 2 & 49 & 8 & \\
\hline Local Officials & & & 100 \\
\hline 3 & 78 & 12 & \\
\hline Former US Senators and State Officials & & & 1.45 \\
\hline 4 & 88 & 1.77 & \\
\hline US Representatives & & & \\
\hline Mean CPQ & 1.43 & & \\
\hline
\end{tabular}

There were 598 challengers assigned a rating, with 10 missing. An independent-sample $t$-test was conducted to compare the political quality of challengers in elections with and without a scandal present. There was no significant difference in the scores for scandal (mean $(\mathrm{M})=1.77, \mathrm{SD}=1.67)$ and no scandal $(\mathrm{M}=1.43, \mathrm{SD}=1.53)$ conditions; $\mathrm{t}(596)=-1.49, p=0.137$.

Table 4 shows that this is true. Challengers in campaigns free from the specter of scandal spent an average of \$2.46 million during this time period, while challengers facing incumbents vulnerable to scandal spent an average of $\$ 3.05$ million. Of course, challenger spending does not happen in a vacuum, and should be considered alongside incumbent spending. Incumbents could ramp up their own spending when facing scandals in an effort to preserve their seats in Congress. Conversely, scandals could limit their ability to acquire the necessary funds to aggressively spend. The data point to the latter. Incumbents free of scandal spent an average of $\$ 4.96$ million, compared to $\$ 4.42$ million for those involved in a scandal. Thus, in an electoral environment where a scandal is present, challengers spend more and incumbents spend less.

To more precisely gauge the impact of scandals on spending in senatorial elections, I calculated a variable that measured the incumbent spending advantage. This variable was calculated by subtracting challenger spending from incumbent spending, and then dividing that number by total spending between the two candidates. A campaign where an incumbent spent all of the money would have a score of 1.00; perfect parity between the two candidates would result in a score of 0.00 ; and a campaign where a challenger spent all of the money would have a score of -1.00 . Put more succinctly, the lower the number, the less of a spending advantage for incumbents. My data reveal that the incumbent spending advantage for elections without a scandal was 0.50 , while the corresponding number for elections with a scandal was 0.30. An independent-sample $t$-test revealed that this difference was statistically significant; thus, I can confirm that scandals have a direct effect on spending in favor of challengers. 
Table 4. Campaign expenditures.

\begin{tabular}{ccc}
\hline & No Scandal & Scandal \\
\hline Incumbents & $\$ 4.96$ million & $\$ 4.42$ million \\
\hline Challengers & $\$ 2.46$ million & $\$ 3.05$ million \\
\hline Spending Advantage & 0.50 & 0.30
\end{tabular}

Spending advantage was calculated by dividing the difference between incumbent expenditures and challenger expenditures by the total expenditures. It ranged from 1.00 (all of the spending was done by an incumbent) to -1.00 (all of the spending was done by a challenger), with 0 representing financial parity. An independent-sample $t$-test was conducted to compare the spending advantage in elections with and without a scandal present. There was a significant difference in the scores for scandal $(\mathrm{M}=0.30, \mathrm{SD}=0.39)$ and no scandal $(\mathrm{M}=0.50, \mathrm{SD}=0.39)$ conditions; $\mathrm{t}(603)=-3.35, p=0.001$

\subsection{The Effect of Scandals on the Vote}

A useful way to determine the impact that scandals have on Senate elections is to estimate their effect on a senator's share of the vote. In order to do this, I performed a multivariate analysis with the incumbent's vote percentage as the dependent variable. ${ }^{14}$ In one equation, I used a dichotomous scandal variable (i.e., where no scandal is equal to zero and the presence of a scandal is equal to one). In the other equation, I assigned scandals to various categories in order to determine whether one type of scandal had more of an impact than others. I adopted the method of categorization used by Basinger (2013), with the addition of a category for controversial statements.

The model also included several other independent variables that were shown to be impactful on congressional elections. Some of these variables measured an incumbent's personal advantages, such as previous vote percentage, number of terms, and incumbent spending advantage. Their opponents may have certain attributes that make a successful challenge more likely, particularly if they have held elected office. This was accounted for by the variable measuring challenger political quality.

Others accounted for the environment within which the incumbent was running. State size was measured as the number of congressional districts in a state. ${ }^{15}$ National partisan swing allowed me to account for the influence of partisan tides by calculating fluctuations in the national popular vote for Senate races. For example, if the partisan swing in a year was six percentage points toward the Democrats, then this variable took on a value of +3.0 for Democratic candidates and -3.0 for Republican candidates. The state partisanship variable recognized the advantage that candidates have if they run in states that align with their partisan affiliation. I relied on the partisan voter index figures published every four years by the Cook Political Report. ${ }^{16}$

14 I calculated the incumbent's share of the two-party vote. There were a few cases where an incumbent faced no opposition from the other major party; thus, the two-party vote was calculated using the third-party candidate with the highest vote total.

15 Unlike House districts, which must be drawn with roughly equal population sizes, small states have dramatically different population sizes compared to large states. For this reason, it was prudent to include a variable capturing these size differences. The existing literature did not offer guidance as to whether this would make a difference on the impact of scandals. One could hypothesize that the effect of scandals would be lessened in larger states with more diverse populations because different groups may react differently to particular scandals. On the other hand, trying to counteract a scandal may be harder in large states because of the difficulty in getting one's message out to a large constituency. The insignificance of this variable suggests that this avenue of inquiry is not warranted.

16 For years prior to the publication of these data, I calculated the scores based on the formula used by the Cook Political Report. Scores were calculated by comparing a state's average two-party presidential vote in the past two presidential elections to the national vote in those same two elections. 
The results of the analysis with the dichotomous scandal variable are displayed in Table $5 .{ }^{17}$ The albatross of scandal translated into a $4 \%$ decline in the popular vote for the senators examined in this study. Although many senators were able to weather such a decline by marshaling their considerable resources, they were forced to operate in a campaign environment where the margin of error narrowed considerably. For others- $40 \%$ in this study-it was too much to overcome. All but two of the other variables were significant and in the expected direction.

Table 5. The impact of scandals on incumbent vote share, 1972-2016.

\begin{tabular}{lcc}
\hline Variable Name & B & SE \\
\hline Scandals & $-4.04^{*}$ & 1.02 \\
\hline Incumbent Previous Vote & $0.17^{*}$ & 0.04 \\
\hline Incumbent Tenure & 0.01 & 0.21 \\
\hline Incumbent Spending Advantage & $11.81^{*}$ & 0.81 \\
\hline Challenger Political Quality & $-1.36^{*}$ & 0.19 \\
\hline State Population Size & -0.06 & 0.03 \\
\hline State Partisanship & $0.23 *$ & 0.04 \\
\hline Partisan Swing & $0.22 *$ & 0.05 \\
\hline Constant & 47.11 & 2.06 \\
\hline Adjusted $R^{2}: 0.57$ & \\
\hline$N: 574$ & \\
\hline \multicolumn{1}{c}{ Ordinary least squares (OLS) model * significant at 0.001.}
\end{tabular}

The results of the analysis with the disaggregated scandal variable are displayed in Table 6. Three of the six types of scandals were significant. Incumbents caught in political scandals suffered a $6.5 \%$ decline in the popular vote. More than half of the incumbents facing such a scandal in the general election ran afoul of campaign finance laws. ${ }^{18}$ The advantage in fundraising enjoyed by incumbents is a primary reason why they are so difficult to unseat, but this advantage can morph into a vulnerability should irregularities arise. Similarly, incumbents committing financial improprieties suffered a $4.6 \%$ decline in the popular vote. Almost all of the incumbents facing such a scandal in the general election were accused of improperly accepting gifts and using the office to enrich themselves. ${ }^{19}$ Even a cynical electorate expects a certain degree of integrity from its public officials, and disapproves of those who use their position of privilege for personal gain. Interestingly, incumbents making controversial statements witnessed a $6.0 \%$ decline in the popular vote. The advent of smart phones capable of recording video and the proliferation of social media sites to distribute that video means that candidates must be on guard even when they are not in the presence of journalists. In the current campaign environment, one verbal gaffe can have serious consequences.

Surprisingly, the coefficients for corruption and sex scandals were not significant. Very few of the incumbents seeking reelection under a cloud of suspicion were accused of the serious crimes part of the corruption category (e.g., bribery and obstruction of justice), but rather used their influence on behalf of political supporters, sometimes with personal benefits accruing to the senators for their

17 I excluded cases where there was no previous vote margin for the incumbent, such as those where the incumbent was appointed to fill a vacancy. I also excluded cases where the incumbent ran unopposed. The small coefficient for previous vote margin seems surprising based on the power of incumbency, but the length of time between elections has a lot to do with this. Whereas the two-year window between House elections means that previous results will be a very good indicator for what lies ahead, the changes to the political landscape that occur within the six years between Senate elections renders previous vote margins less meaningful.

18 There were seven such incumbents, with four of them involved in campaign finance irregularities.

19 There were 12 such incumbents, with 10 of them accused of improperly accepting gifts and enriching themselves. 
actions. This behavior was often more ambiguous than clearly defined violations of the law. Still, one would expect that unethical behavior in office, even if not illegal, would be detrimental to a campaign. Perhaps another mitigating factor is that some of the senators in this category actually had reputations for probity prior to the scandals; thus, voters were willing to give them the benefit of the doubt. ${ }^{20}$

The conventional wisdom is that public officials are held to a higher standard in terms of personal conduct, such that immoral behavior will negatively affect their reelection chances. This is especially true of Republican officials who often run on a platform that explicitly champions moral values. Previous studies found that sex scandals significantly impact vote totals (Basinger 2013; Brown 2006; Cobb and Taylor 2014; Peters and Welch 1980; Welch and Hibbing 1997). However, those studies excluded other important variables, such as campaign spending, challenger political quality, state/district partisanship, and electoral tides. Excluding those variables from my model would also produce a statistically significant sex scandal variable. ${ }^{21} \mathrm{I}$ think this resulted in an underspecified model that did not reflect the true impact of various types of scandals on candidate performance. The robust model presented in this paper more accurately reflected the impact of sexual improprieties, and, although the variable itself was insignificant, a closer examination of the data revealed a more nuanced situation.

Table 6. The impact of types of scandals on incumbent vote share, 1972-2016.

\begin{tabular}{lcc}
\hline Variable Name & B & SE \\
\hline Financial Scandals & $-4.57^{* * *}$ & 1.96 \\
\hline Political Scandals & $-6.52^{* *}$ & 2.51 \\
\hline Corruption & -0.89 & 2.09 \\
\hline Sex Scandals & -3.93 & 3.34 \\
\hline Controversial Statements & $-6.03^{* *}$ & 2.38 \\
\hline Other Scandals & 0.54 & 2.15 \\
\hline Incumbent Previous Vote & $0.17^{*}$ & 0.04 \\
\hline Incumbent Tenure & -0.003 & 0.21 \\
\hline Incumbent Spending Advantage & $11.55^{*}$ & 0.81 \\
\hline Challenger Political Quality & $-1.40^{*}$ & 0.19 \\
\hline State Population Size & -0.05 & 0.03 \\
\hline State Partisanship & $0.23 *$ & 0.04 \\
\hline Partisan Swing & $0.22 *$ \\
\hline Constant & 47.38 \\
\hline Adjusted $R^{2}: 0.57$ & & 0.05 \\
\hline$N: 574$ & & \\
\hline OS model; ${ }^{*}$ significant at $0.001{ }^{* *}$ significant at $0.01{ }^{* * *}$ significant at 0.05 \\
\hline
\end{tabular}

20 There were 11 such incumbents, with nine of them accused of improperly using their influence on behalf of an individual or business. The senators with honest reputations who were accused of such behavior include John Glenn, Orin Hatch, Mark Hatfield, John McCain, and Paul Simon.

$21 \quad$ Beta $=11.12 ; \mathrm{SE}=4.92 ; p<0.05$ 
Those senators accused of the most serious sexual misbehavior did not even bother to seek reelection. ${ }^{22}$ Thus, sex scandals did have a negative impact on them, but it was not manifested by smaller vote totals. Two senators who did seek reelection were defeated. Both were one-term Republicans from socially conservative states who had won their previous elections by small margins. The scandals caused each of their vote percentages to decrease by seven percentage points. ${ }^{23}$ Thus, sex scandals impacted their general election vote totals as expected.

Of the three senators that were reelected, two of them achieved victory despite large drops in their vote totals. Bob Dole's (R-KS) divorce from his wife and affair with a younger woman in 1974 was relatively tame compared to the behavior of some his colleagues. Although his share of the vote did drop by $10 \%$ from his previous election, it had more to do with the inhospitable electoral environment for Republicans after Watergate than his marital problems. Likewise, Charles Robb (D-VA) certainly was not helped by revelations of marital infidelity during his 1994 reelection campaign. The fact that he was a Democrat running in a conservative state in a wave election that favored Republicans coupled with the spending advantage of his opponent were equally important factors in his $20 \%$ drop from his previous election.

The only outlier is David Vitter (R-LA). A social conservative admitting to using the services of prostitutes should be vulnerable at the polls, but he actually increased his percentage of the vote by $9 \%$ during his 2010 reelection victory. He was aided by the momentum generated for Republicans by the Tea Party movement, as well as by the partisanship of the state. This fortuitous timing did not last, as the scandal featured prominently in a later gubernatorial campaign where he was soundly defeated.

\section{Conclusions}

This study provides conclusive evidence that scandals have negative electoral consequences for incumbents seeking reelection to the Senate. Senators involved in scandals during the period of time covered by this study lost an average of four percentage points at the polls. Those involved in political and financial scandals, as well as those making controversial statements, were harmed the most. This study differs from others in its finding that sexual indiscretions are not a significant cause of the loss of electoral support. It is not that such acts are overlooked by voters, but rather that other factors dampen the impact of such indiscretions on the vote.

The harsh electoral climate made it more likely that scandal-plagued incumbents would fail to return to Capitol Hill. Only $60 \%$ of those running in a general election were victorious, and when factoring in members who resigned, retired, and were defeated in primaries, only $42 \%$ remained in office. Exacerbating their troubles was the fact that vulnerable incumbents faced challengers who were better financed than challengers they might ordinarily encounter. Campaign expenditures have a meaningful impact on the vote, and challengers who are able to minimize or erase the traditional spending advantage that incumbents enjoy are better positioned to capitalize on the diminution of support that results from scandals.

The findings in this study shed light on an important aspect of congressional elections. However, there are still plenty of areas to be explored. It would be interesting to see how voters react to scandals by tracking patterns of campaign contributions before and after scandals occur, and combining that with an examination of how candidates alter patterns of spending. In an era of increased partisanship, do voters react differently to scandals based on their party identification, and do the political characteristics of states influence the types of scandals and their impact? It would also be useful to know whether the emergence of digital technology changes how the electorate responds to

22 Brock Adams (D-WA) was accused of sexual assault and Robert Packwood (R-OR) was accused of sexual harassment. John Ensign (R-NV) had an affair that resulted in violations of financial laws and obstruction of justice. Larry Craig (R-ID) solicited another man in an airport bathroom.

23 Roger Jepsen (R-IA) won his previous election by 51\%, but his percentage dropped to $44 \%$ in his 1984 defeat. Tim Hutchinson (R-AR) won his previous election by $53 \%$, but his percentage dropped to $46 \%$ in his 2002 defeat. 
these incidents. Social media amplifies scandals and provides voters a platform for discussing them; thus, it stands to reason that the impact of scandals will be altered by this new digital landscape.

Funding: This research received no external funding.

Conflicts of Interest: The author declares no conflict of interest.

\section{References}

Abramowitz, Alan I. 1988. Explaining Senate Election Outcomes. American Political Science Review 82: $385-403$. [CrossRef]

Abramowitz, Alan I. 1991. Incumbency, Campaign Spending, and the Decline of Competition in U.S. House Elections. Journal of Politics 53: 34-56. [CrossRef]

Abramowitz, Alan I., and Jeffrey A. Segal. 1992. Senate Elections. Ann Arbor: University of Michigan Press.

Alford, John, Holly Teeters, Daniel S. Ward, and Rick K. Wilson. 1994. Overdraft: The Political Cost of Congressional Malfeasance. The Journal of Politics 56: 788-801. [CrossRef]

Ansolabehere, Stephen, and Alan Gerber. 1994. The Mismeasure of Campaign Spending: Evidence from the 1990 U.S. House Elections. Journal of Politics 56: 1106-18. [CrossRef]

Baker, Richard. 1985. The History of Congressional Ethics. In Representation and Responsibility: Exploring Legislative Ethics. Edited by Bruce Jennings and Daniel Callahan. New York: Plenum Press.

Banducci, Susan A., and Jeffrey A. Karp. 1994. The Electoral Consequences of Scandal and Reapportionment in the 1992 House Elections. American Politics Quarterly 22: 3-26. [CrossRef]

Basinger, Scott J. 2013. Scandals and Congressional Elections in the Post-Watergate Era. Political Research Quarterly 66: 385-98. [CrossRef]

Bauer, Monica, and John R. Hibbing. 1989. Which Incumbents Lose in House Elections: A Response to Jacobson's 'The Marginals Never Vanished. American Journal of Political Science 33: 262-71. [CrossRef]

Boatright, Robert G. 2013. Getting Primaried: The Changing Politics of Congressional Primary Challenges. Ann Arbor: University of Michigan Press.

Bowler, Shaun, and Jeffrey A. Karp. 2004. Politicians, Scandals, and Trust in Government. Political Behavior 26: 271-87. [CrossRef]

Brace, Paul. 1984. Progressive Ambition in the House: A Probabilistic Approach. Journal of Politics 46: 556-69. [CrossRef]

Brown, Lara Michelle. 2006. Revisiting the Character of Congress: Scandals in the U.S. House of Representatives, 1966-2002. Journal of Political Marketing 5: 149-72. [CrossRef]

Brown, Lara M. 2007. It's Good to Be an Incumbent: Scandals, Corruption, and the 2006 Midterm Election. Legislative Studies Section Newsletter 30: 74-86.

Butler, Anne M., and Wendy Wolff. 1995. United States Senate Election, Expulsion and Censure Cases: 1793-1990. Prepared by the U.S. Senate Historical Office, 103rd Congress, 1st Session, S.Doc. 103-33. Washington: GPO.

Carlson, James, Gladys Ganiel, and Mark S. Hyde. 2000. Scandal and Political Candidate Image. Southeastern Political Review 28: 747-57. [CrossRef]

Chang, Eric C.C., Miriam A. Golden, and Seth J. Hill. 2010. Legislative Malfeasance and Political Accountability. World Politics 62: 177-220. [CrossRef]

Cobb, Michael D., and Andrew J. Taylor. 2014. Paging Congressional Democrats: It Was the Immorality, Stupid. PS: Political Science and Politics 47: 351-56. [CrossRef]

Congressional Quarterly. 1992. Congressional Ethics: History, Facts, and Controversy. Washington: CQ Roll Call.

Dancey, Logan. 2012. The Consequences of Political Cynicism: How Cynicism Shapes Citizens' Reactions to Political Scandals. Political Behavior 34: 411-23. [CrossRef]

Dimock, Michael A., and Gary C. Jacobson. 1995. Checks and Choices: The House Bank Scandal's Impact on Voters in 1992. The Journal of Politics 57: 1143-59. [CrossRef]

Doherty, David, Conor M. Dowling, and Michael G. Miller. 2011. Are Financial or Moral Scandals Worse? It Depends. PS: Political Science and Politics 44: 749-57. [CrossRef]

Erikson, Robert S. 1971. Th Advantage of Incumbency in Congressional Elections. Polity 3: 395-405. [CrossRef]

Funk, Carolyn L. 1996. The Impact of Scandal on Candidate Evaluations: An Experimental Test of the Role of Candidate Traits. Political Behavior 18: 1-24. [CrossRef] 
Garment, Suzanne. 1992. Scandal: The Culture of Mistrust in American Politics. New York: Anchor Books.

Gelman, Andrew, and Gary King. 1990. Estimating Incumbency Advantage without Bias. American Journal of Political Science 34: 1142-64. [CrossRef]

Ginsberg, Benjamin, and Martin Shefter. 1990. Politics by Other Means: The Declining Importance of Elections in America. New York: Basic Books.

Grossman, Mark. 2008. Political Corruption in America: An Encyclopedia of Scandals, Power, and Greed, 2nd ed. Amenia: Grey House.

Herrick, Rebekah. 2000. Who Will Survive? An Exploration of Factors Contributing to the Removal of Unethical House Members. American Politics Quarterly 28: 96-109. [CrossRef]

Herrick, Rebekah. 2003. Fashioning the More Ethical Representative: The Impact of Ethics Reforms in the U.S. House of Representatives. Westport: Praeger Publishers.

Heywood, Paul. 1997. Political Corruption: Problems and Perspectives. Political Studies 45: 417-35. [CrossRef]

Hibbing, John R., and Elizabeth Theiss-Morse. 1995. Congress as Public Enemy: Public Attitudes toward American Political Institutions. Cambridge: Cambridge University Press.

Jacobson, Gary C. 1978. The Effects of Campaign Spending in Congressional Elections. American Political Science Review 72: 469-91. [CrossRef]

Jacobson, Gary C. 2009. The Politics of Congressional Elections, 7th ed. New York: Longman.

Jacobson, Gary C., and Michael A. Dimock. 1994. “Checking Out: The Effects of Bank Overdrafts on the 1992 House Elections. American Journal of Political Science 38: 601-24. [CrossRef]

Kebschull, Harvey G. 1992. Political Corruption: Making It the 'Significant Other' in Political Studies. PS: Political Science and Politics 25: 705-9.

Kenny, Christopher, and Michael McBurnett. 1994. An Individual-Level Multiequation Model of Expenditure Effects in Contested House Elections. American Political Science Review 88: 699-707. [CrossRef]

Kessler, Ronald. 1997. Inside Congress: The Shocking Scandals, Corruption, and Abuse of Power Behind the Scenes on Capitol Hill. New York: Pocket Books.

Kiewiet, D. Roderick, and Langche Zeng. 1993. An Analysis of Congressional Career Decisions, $1974-86$. American Political Science Review 87: 928-41. [CrossRef]

Krasno, Jonathan S., and Donald Philip Green. 1988. Preempting Quality Challengers in House Elections. The Journal of Politics 50: 920-36. [CrossRef]

Long, Kim. 2007. The Almanac of Political Corruption, Scandals, and Dirty Politics. New York: Delacorte.

Lublin, David Ian. 1994. Quality, Not Quantity: Strategic Politicians in U.S. Senate Elections, 1952-1990. Journal of Politics 56: 228-41. [CrossRef]

Marion, Nancy. 2010. The Politics of Disgrace: The Role of Political Scandal in American Politics. Durham: Carolina Academic Press.

Markovits, Andrei, and Mark Silverstein, eds. 1988. The Politics of Scandal: Power and Process in Liberal Democracies. New York: Holmes \& Meier.

Mayhew, David R. 1974. Congressional Elections: The Case of the Vanishing Marginals. Polity 6: $295-317$. [CrossRef]

Miller, Arthur H. 1999. Sex, Politics, and Public Opinion: What Political Scientists Really Learned from the Clinton-Lewinsky Scandal. PS: Political Science and Politics 32: 721-29.

Min, Jeonghun. 2013. The Influence of Scandal on Vote Intention during Korean Presidential Campaigns: Why Do Voters Support the 'Corrupt' Candidate? Asian Survey 53: 393-422. [CrossRef]

Ornstein, Norman. 1993. Less Seems More: What to Do about Contemporary Political Corruption. The Responsive Community 4: 7-22.

Parker, David C. W., and Matthew Dull. 2009. Divided We Quarrel: The Politics of Congressional Investigations, 1947-2004. Legislative Studies Quarterly 34: 319-45. [CrossRef]

Patterson, Samuel C., and Gregory A. Caldeira. 1990. Standing Up for Congress: Variations in Public Esteem Since the 1960s. Legislative Studies Quarterly 15: 25-47. [CrossRef]

Peters, John G., and Susan Welch. 1980. The Effects of Charges of Corruption on Voting Behavior in Congressional Elections. American Political Science Review 74: 697-708. [CrossRef]

Praino, Rodrigo, Daniel Stockemer, and Vincent G. Moscardelli. 2013. The Lingering Effect of Scandals in Congressional Elections: Incumbents, Challengers, and Voters. Social Science Quarterly 94: 1045-61. [CrossRef] 
Puglisi, Riccardo, and James M. Snyder Jr. 2011. Newspaper Coverage of Political Scandals. The Journal of Politics 73: 931-50. [CrossRef]

Roberds, Stephen C. 2003. Do Congressional Ethics Committees Matter? U.S. Senate Ethics Cases, 1789-2000. Public Integrity 6: 25-38.

Roberts, Robert N. 2001. Ethics in Government: An Encyclopedia of Investigations, Scandals, Reforms, and Legislation. Westport: Greenwood Press.

Rohde, David. 1979. "Risk-Bearing and Progressive Ambition: The Case of Members of the United States House of Representatives. American Journal of Political Science 23: 1-26. [CrossRef]

Romano, Michael K. 2014. Tuning in to Scandal: Television News Coverage of Congressional Scandals. PS: Political Science and Politics 47: 386-90. [CrossRef]

Rosenson, Beth. 2014. Ethics Evolving: Unethical Political Behavior Viewed Through The Lens of U.S. House Ethics Investigations, 1798-2011. Public Integrity 16: 227-41. [CrossRef]

Rundquist, Barry S., Gerald S. Strom, and John G. Peters. 1977. Corrupt Politicians and Their Electoral Support: Some Experimental Observations. American Political Science Review 71: 954-63. [CrossRef]

Sabato, Larry J., Mark Stencel, and S. Robert Lichter. 2000. Peep Show: Media and Politics in an Age of Scandal. Lanham: Rowman and Littlefield.

Thompson, Dennis F. 1995. Ethics in Congress: From Individual to Institutional Corruption. Washington: The Brookings Institution.

Tolchin, Martin, and Susan J. Tolchin. 2001. Glass Houses: Congressional Ethics and the Politics of Venom. Boulder: Westview Press.

Vonnahme, Beth Miller. 2014. Surviving Scandal: An Exploration of the Immediate and Lasting Effects of Scandal on Candidate Evaluation. Social Science Quarterly 95: 1308-21. [CrossRef]

Welch, Susan, and John R. Hibbing. 1997. The Effects of Charges of Corruption on Voting Behavior in Congressional Elections, 1982-1990. Journal of Politics 59: 226-39. [CrossRef]

(C) 2019 by the author. Licensee MDPI, Basel, Switzerland. This article is an open access article distributed under the terms and conditions of the Creative Commons Attribution (CC BY) license (http:/ / creativecommons.org/licenses/by/4.0/). 